\title{
OS IMIGRANTES PORTUGUESES E A DEVOÇÃO DE FÁTIMA EM PARIS
}

Sidnei Marco Dornelas*

1 imigração portuguesa em território francês está para completar 30 $\operatorname{anos}^{1}$. Esta população constitui hoje o segundo maior grupo de estrangeiros depois dos argelinos, com cerca de 800 mil pessoas. Eles se concentram sobretudo na Região Parisiense, e têm uma presença considerável nas indústrias de construção civil e nos trabalhos de limpeza nos escritórios dos grandescentros. Apesar do grande número, eles passam quase despercebidos na sua rotina de trabalho infatigável. Ao contrário dos imigrantes muçulmanos do norte da África, cuja presença é motivo de um mal estar crescente entre os franceses, o português é apontado como um exemplo de imigrante que conseguiu se integrar com sucesso na sociedade francesa. Trabalhador, obediente, discreto, branco, europeu, religioso, católico...

O debate inflamado sobre "identidades" nacionais que angustia o cenário político europeu the é completamente estranho. Ele não teria um problema de identidade mal resolvido como os remanescentes dos países que saíram do colonialismo. Tanta facilidade de se integrar acaba por levantar algumas interrogações. Em outros termos, como os portugueses, camponeses saidos dos recantos mais arcaicos da Europa, puderam resolver com aparente tanta facilidade seu problema de "identidade cultural'" numa França em pleno capitalismo pós-industrial ? Como eles administram a sua integração neste país tão indiferente ao que eles são ou foram, sem violentar a herança cultural de suas origens ?

Essas perguntas, ainda superficiais, constituíram o pano de fundo de uma série de estudos realizados na década passada sobre a irrupção de inúmeras associações culturais portuguesas em toda a França. A pergunta sobre como os imigrantes estruturam sua identidade coletiva na sociedade estrangeira, meio hostil que os explora, acompanha atualmente o exame de todas as suas práticas culturais associativas. Deste universo vasto, nós destacamos um tipo de associação muito particular: a comunidade católica portuguesa. E de suas práticas culturais, uma toda especial: a veneração e a festa em honra a Nossa Senhora de Fátima (NSF) na Região Parisiense. E nos perguntamos: como os portugueses se servem do espaço eclesial francês para reconstruir a sua identidade cultural? Ou de maneira mais precisa, qual o lugar de NSF neste processo de estruturação da identidade cultural do emigrante/imigrante português a partir de suas práticas culturais/religiosas num país estrangeiro?

\section{As comunidades católicas portuguesas na Região Parisiense}

A Igreja Católica francesa tem sido uma das instituições que mais espaço tem aberto para a prática religiosa dos imigrantes estrangeiros. Os portugueses difundiram suas comunidades com relativa calma, apesar dos inevitáveis atritos com os párocos e leigos franceses. As comunidades portuguesas se instalam nas dependências de paróquias francesas, o que as obrigam a conviver com a programação religiosa francesa. Os agentes pastorais franceses têm dificuldade em aceitar uma comunidade estrangeira, com uma programação paralela à sua, e que pode provavel- mente lhes fugir ao controle. Conscientes desta hostilidade em potencial, os líderes portugueses se obrigam constantemente a negociar com as "autoridades francesas", no caso o pároco local, a utilização do espaço para a expressão de suas práticas culturais/religiosas. Eles procuram o aval da autoridade local para obter a kegitimidade de sua presença neste espaço fráncês.

O ponto de referência para o encontro dos imigrantes é a missa em língua portuguesa, e sua principal atividade, a catequese em língua portuguesa. Celebram-se também os sacramentos, vividos como ritos de passagem: batismos, casamentos, etc. As festas típicas portuguesas são obrigatórias, num ritmo que se repete ano após ano. Se a comunidade é um lugar de oração, ela é também, e principalmente, um lugar para o encontro e convivência dos imigrantes portugueses. Um lugar onde eles podem recobrar as suas referências culturais originais, ao abrigo das solicitações da sociedade de imigração. A comunidade, pela teia de relações que cria, tende a reproduzir as relações sociais outrora vividas nos vilarejos camponeses de Portugal, e se apresenta como uma extensão das relações de subordinação existentes no interior da família. Como as relações internas à família estão muitas vezes abaladas pela influência da sociedade francesa, as estruturas "associativas" da comunidade católica vêm em seu socorro, reforçando-as. Daí a solicitação da catequese em língua portuguesa para crianças que só sabem o francês, e a insistência para que ela se faça tal qual se fazia antigamente, nas "freguesias" camponesas do norte de Portugal.

As festas seguem este mesmo espírito de recriar e reviver o ambiente e os laços 
das "aldeias" portuguesas: pela alimentação e bebida consumida, pelas músicas tocadas, pelas danças, pelo modo de falar e discutir, pela forma de ocupar os ambientes, pelo tipo de devoção praticada... Nesse sentido, as celebrações em honra a NSF ocupam um lugar especial. Ao contrário das associações leigas, a maioria das comunidades católicas suprimiram das celebrações a parte dita profana, talvez por se envergonharem pelo seu lado "típico português", exageradamente explícito. $\mathrm{Na}$ realidade, as festas a NSF, preparadas com relativa espontaneidade por qualquer associação, constituem-se na grande Festa Nacional dos portugueses no exterior. As comunidades católicas portuguesas, resguardando apenas o lado religioso da festa, visam ressaltar o lado devocional para si mesmos e para a sociedade onde estão situados. É sobre esta função de uma prática religiosa/cultural que queremos nos deter: como através da realização desta prática os imigrantes portugueses reconstróem/reestruturam sua identidade cultural ?

\section{A religião como representação e vontade de ser português}

Em entrevistas que realizamos com vários leigos participantes de comunidades portuguesas, pudemos perceber como o culto a NSF é motivo de um envolvimento apaixonado: uns são a favor, outros são contra. Pode parecer estranho, mas existem alguns portugueses católicos que são reticentes ao culto prestado a NSF. São aqueles militantes da ACO (Ação Católica Operária) que, à força de um longo processo de formação e de reciclagem dentro de ambientes franceses, redimensionaram seus referenciais religiosos e culturais. Criticam o apego exclusivista dos portugueses à imagem de NSF, o devocionismo que coloca na sombra a dimensão evangélica da fé, o ambiente de quermesse que acompanha suas festas, a falta de compromisso dos participantes, a rigidez do ritualismo, etc. No entanto, a grande maioria dos imigrantes portugueses têm um apego apai- xonado a NSF, e ela exerce uma função quase mitológica de dar unidade e sentido à história e condição de vida dos portugueses no exterior ${ }^{2}$

O objeto essencial para concretizar a devoção a NSF é a sua imagem. Sem ela não é possível realizar qualquer tipo de celebração religiosa, ou mesmo pensar em reunir os portugueses para tal. O primeiro aspecto a ressaltar é como todo o processo para encontrá-la e organizar a festa passa ao largo da autoridade dos padres, sejam eles o pároco francês ou mesmo o capelão da comunidade portuguesa. Se a imagem é emprestada de outra comunidade, eles devem antes pedir a autorização à pessoa que doou a imagem àquela comunidade que a está emprestando. É como se essa pessoa ainda tivesse um poder sobre a imagem em vias de ser emprestada. Se a imagem é comprada, existe um longo trajeto que passa pela coleta de dinheiro entre todos os imigrantes da comunidade, a encomenda, o transporte, a bênção, a festa da acolhida, e toda a organização que isso implica- tudo isso com a "permissão" do padre, mas sem sua intervenção direta. Assim, a imagem é um objeto simbólico sobre o qual o padre não tem um poder real, e que os portugueses administram de maneira autônoma, segundo suas próprias necessidades. Os portugueses servem-se do padre para presidir a celebração e obter a autorização para que a imagem fique (ou não) dentro da igreja - isto é, a função de legitimar o culto e o uso da imagem. Desta maneira, é natural que os padres franceses, formados no espírito secularizante do Concílio Vaticano II, manifestem as suas reservas ao culto a NSF - como eles já o manifestam em relação ao culto de santos em geral, que eles consideram uma demonstração de superstição e idolatria.

A relação dos imigrantes portugueses com NSF guarda semelhanças com o culto dos santos, já bastante estudado pelas ciências sociais. Estes imigrantes, camponeses na sua mais profunda intimidade, encontram nos santos aquilo que os ritos "oficiais' do catolicismo não conseguem oferecer: a vivência mais pessoal, íntima, afetiva e autônoma de sua fé. O contato com a imagem dos santos é todo personalizado: nas palavras e gestos manifestam-se o respeito, o sentimento de filiação, as queixas, a afetividade, o agradecimento. Esta ligação afetiva, emocional, explica o desgosto de um português diante do desprezo dos padres franceses ao culto dos santos:

“...porque, por exemplo, naigreja onde a gente faz a missa, há uma pessoa que guarda a igreja que é portuguesa. Quando a gente combinou a imagem ela disse: 'Ah! vocês vão comprar uma imagem? Pra que? Pra botar na venda? Pra botar no lixo? Tínhamos tantas imagens aqui nesta igreja, que era tão linda! E eles mandaram vir um caminhão pra meter tudo, tudo no lixo... 'Os padres franceses mandaram vir um caminhão e esvaziaram a igreja de todos os santos que lá havia, e meteram tudo no lixo... Eh! bom... Os portugueses não gostam, não gostam. E pouco a pouco, pouco a pouco, as igrejas vão ficar só com uma cruz, vazias de tudo, só com uma cruz. Por que, por exemplo, aqui em Saint Joseph, tinha Nossa Senhora lá em cima, a beira do altar-mor ; pois agora desceram-na para o fundo. Agora está lá no fundo. E Santa Maria, também estava a beira do altar, à esquerda, ali com as velas e tudo isso ; já está no fundo também. É uma maneira triste... As igrejas são tristes na França. São tristes não é... Ninguém mais vai, o povo não vai mais lá, só alguns campagnards ${ }^{3}$ da região parisiense... ",

Para os portugueses, jogar as imagens " no lixo" soa como um escândalo. Retirálas do lado do altar para colocá-las no fundo significa relegá-las a uma segunda classe. A descrição da retirada das imagens da igreja surge como uma operação de despovoamento. A igreja fica vazia, sem nada, só com uma cruz. Quando se sabe que a cruz é o símbolo mesmo do suplício do Cristo, compreende-se o sentimento de tristeza desse português, que não tem mais ninguém a quem se dirigir a não ser esta cruz triste. Nesta descrição, o despovoamento da igreja dos seus santos, que lhe davam a alegria e a beleza pelas imagens que lhe representavam, é acompanhada por um despovoamento real, pois o povo não vai mais.

A imagem de NSF, e a celebração que 
se realiza em torno dela, buscam explicitamente o efeito contrário. A coletividade portuguesa serve-se dessa ocasião para se fazer reconhecer diante de si mesma, e eventualmente diante da sociedade francesa. Eles celebram-na dentro do espaço eclesial, mas num local e num tempo negociados, que eles evitam ultrapassar para não provocar conflitos maiores. Vista com desconfiança pelos padres e comunidade francesa, a celebração a NSF é assim realizada num espaço reservado aos portugueses. Ela é por excelência a santa de devoção dos imigrantes portugueses, que não poupam esforços para criar um espetáculo visual belo e requintado. O maravilhoso da imagem enfeitada se associa ao lado espetacular da festa que reúne a massa dos portugueses. Todas as atividades são realizadas para satisfazer a dimensão do "ver' ': as flores, o andor, a igreja decorada, as fotografias, os brocados, etc... A vaidade e o ciúme que os portugueses demonstram em relação à imagem enfeitada nos sugerem que eles estão, no ato de embelezar a imagem, embelezando a sua própria imagem de portugueses num país estrangeiro. As celebrações em honra a NSF são a ocasião para estes imigrantes se mostrarem diante deles mesmos, e diante dos outros, de maneira positiva.

NSF exerce assim o efeito de reunir os portugueses e re-soldar de maneira ritual sua identidade cultural de imigrante português, ao devolver sentido ao seu projeto migratório. NSF os acompanhou em todo o seu percurso: ela lhes lembra a terra de origem e a fé atualmente desvalorizada que corre o risco de desaparecer, as agruras cotidianas na terra de imigração, os filhos que não correspondem ao seu ideal de educação. NSF representa, com efeito, a transcendência que os acompanha e se faz íntima de todos aqueles que carregam o projeto migratório. Decorar a imagem e mostrá-la a todo o povo significa uma projeção do ser português diante deles mesmos, onde é exaltado o seu lado maravilhoso, irretocável. Desse modo, levantar o andor e andar com ele é uma maneira especial de apresentar essa imagem, para que ela possa ver a todos, e todos possam vê-la, e assim uma mútua identificação possa acontecer. Uma portuguesa nos relata esse tipo de experiência:

“ 'Costumo enfeitar à nossa maneira o andor, e então pedi aos senhores padres aquele que tiver a 'melhor boavontade' de fazer uma procissãozinha lá dentro da igreja. Simplesmente pra que Nossa Senhora... pra que possamos de uma maneira especial termos-a mais perto de nós, mais junto de nós evermos-a mais de perto pra ver se com essas coisicas... renovaro coração de certas pessoas que andam assim afastadas.

\section{(...)}

Nossa Senhora foi o primeiro sacrário na terra, de maneira que... lembrei-me... fazendo alguma coisa... porque o que não se diz, esquece... Uma vez que ela está aqui, porque não fazer alguma coisa pra que todos vejam, pra que a gente vendo, haja sempre uma outra maneira de pensar a nossa vida, outra reação. E se eu vivesse mais perto dessa mãe que tanto nos ama. Faz-nos lembrar outras, outras coisas que ela nos pediu em Fátima, quando ela apareceu. Outras coisas boas que a gente podia, podia viver melhor... '

Neste jogo de olhares, se poderá talvez superar a ameaça do esquecimento que espreita o cotidiano em que vivem os imigrantes portugueses. Os leigos católicos portugueses concentram na celebração à NSF todos os esforços para despertar a lembrança da fé que eles viveram um dia em Portugal, e que eles ainda carregam na sua memória. Eles acreditam no poder de NSF em transformar o coração das pessoas, e assim, o seu comportamento. Em $\mathrm{NSF}$, nas celebrações religiosas em torno da imagem que a torna presente, se cristalizam os desejos e as necessidades mais profundas dos imigrantes portugueses na França. Eles têm necessidade de exprimilos, de falar, de dizer, para que tudo não caia na vala comum do esquecimento. Eles tentam tudo re-ligar - o passado, o presente e o futuro - e assim recuperar, ao mesmo tempo que o transformam, o sentido originário do projeto migratório.

Enfim, é a religião, através do agenciamento da memória coletiva, que está reconstituindo a identidade cultural destes emigrantes/imigrantes portugueses. $\mathrm{O}$ ato de ver e lembrar no interior dos rituais que marcam a celebração a NSF estãocondicionados pelos mecanismos que levam à produção da crença e da eficácia simbólica ${ }^{4}$. A dialética entre a experiência íntima e a imagem social exprime bem o encontro entre o desejo e a devoção íntima que cada imigrante alimenta, e a imagem que sintetiza e sacraliza a imagem social que os imigrantes querem dar de si mesmos. O "ver' é uma dimensão essencial da celebração, e todos os preparativos concorrem para a sua completa realização. Pelo ver se realiza o jogo de olhares pelos quais os indivíduos podem se assumir de maneira positiva como portugueses imigrantes, e a imagem pode reunir este grupo lhe dando unidade e sentido. $\mathrm{O}$ andor levantado, em procissão, realiza a "circulação mágica" que produz a crença, entretida por todos e pelo grupo como um todo, que vai constituir a identidade cultural que os portugueses querem se dar. Assim, a memória e a crença se reforçam dentro de um mesmo processo: ver-lembrar-crer faz parte do movimento de espírito que vai reconstituir a unidade significativa de suas vidas. A memória realiza então essa função de re-ligar, própria à religião. A religião, por um efeito de consagração, pode assim dar unidade ao que o desenraizamento espacial e a dissolução temporal condenam à desintegração, ao esquecimento

* Sidnei Marco Dornelas é padre carlista, integrante da equipe do CEM.

\section{NOTAS}

1. Este artigo sintetiza alguns aspectos estudados pelo autor na Dissertação de Mestrado "Laics Portugais dans IEglise de France : La place de la religion dans la structuration de lidentite cullturelle chez les immigrés cathollques portugals en lle-de. France", Paris, IES/institut Catholique de Paris, 1992 mimeo

2. Cr. Lopes, Policarpo, "Le pèlerinage à Fátima Processus d'une transaction entre tradition et moderrité à partir d'une situation migratoire", Soclal Compass (33), 1, 1986, Centre de Recherches Sociologiques, Louvain, pp. 91-106 ;

3- Campagnards: pessoas que vềm do campo. 4- Cf. Levi-Strauss, Claude, "Antropologla Estrutural", caps. IX eX ; cf. também Bourdieu, Pierre, "Gênese e Estrutura do Campo Religioso", in "A Economla das Trocas Simbblicas", São Paulo, Perspectiva, $1987,2^{2}$ ediçăo. pp. 54 ss : 